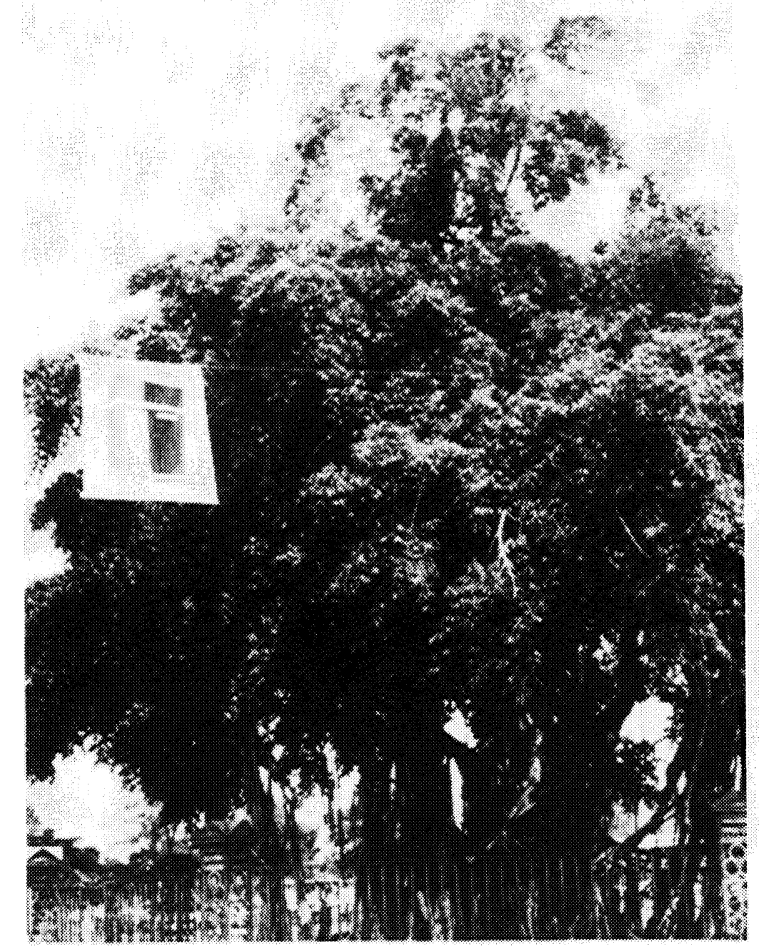

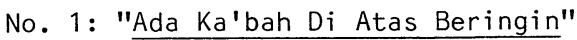

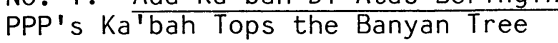

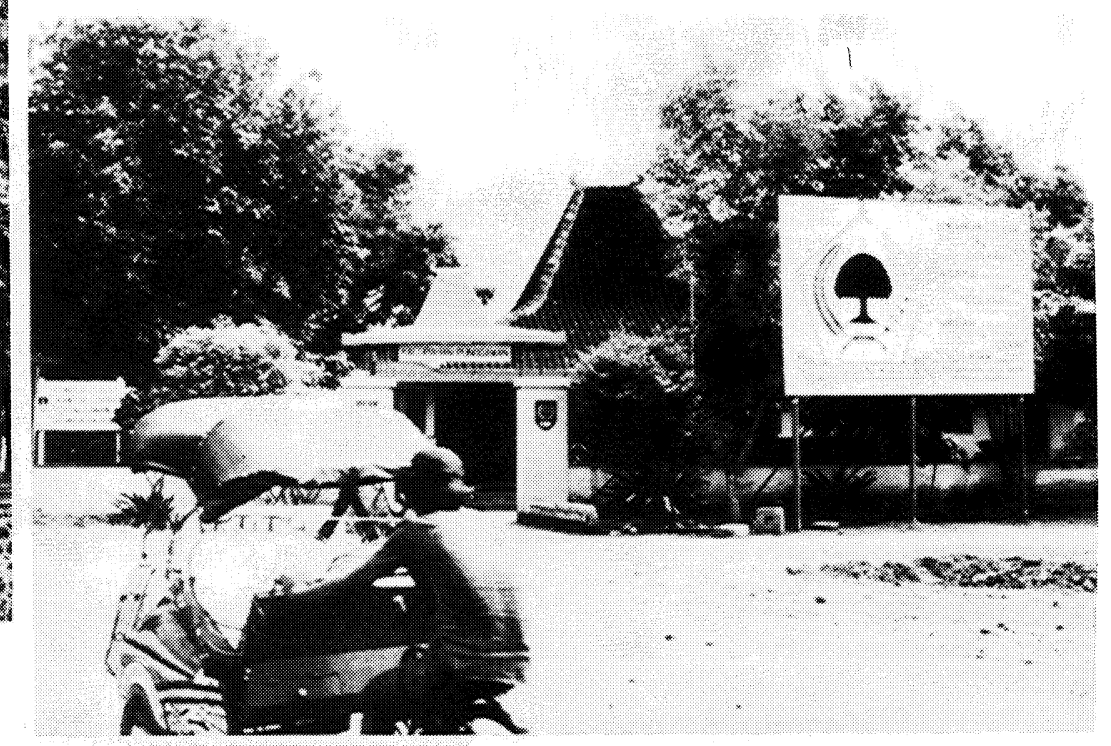

No. 2: Gateway to Local Government

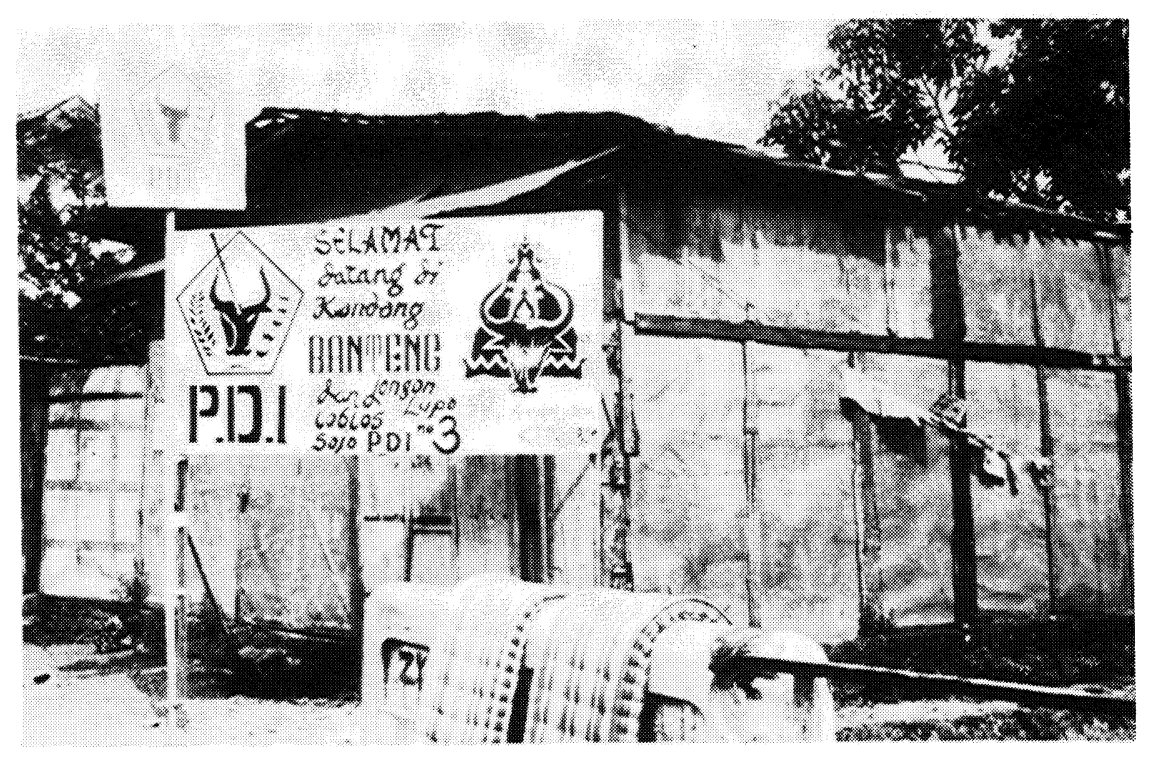

No. 3: "Welcome to PDI's Bull Pen" 


\title{
NOTES ON THE 1982 GENERAL ELECTION IN SOLO*
}

\author{
John Pemberton
}

\begin{abstract}
Historical events of ten seem more important to their witnesses than they do to historians who judge them later. When this thesis was completed in September 1972 it still appeared to me that the election it describes was a major landmark in the consolidation of the Suharto government and I thought that the enormous social problems apparently ignored by Suharto would not prevent his administration from surviving for many years. Now as I write in the wake of the January 1974 demonstrations that rocked Djakarta, the solidity of the $\mathrm{New}$ Order appears to have been a very ephemeral thing indeed and divisions within the armed forces in particular have been laid bare. Few Indonesians would wager that another twenty years will be given to the New Order to carry out its programme of accelerated modernization.
\end{abstract}

\section{Ken Ward, The 1971 Election in Indonesia 1}

The first signs of the 1982 Indonesian national election in Solo's neighborhoods were the concentrated efforts of local teenage boys removing motorcycle mufflers and the sudden appearance of hundreds of campaign posters. This was one morning in mid March. Within hours, the streets of the small but densely populated Central Javanese city of one-half million buzzed in anticipation of the April political campaigns leading up to election day, May 4. Thus began the third in a series of general elections completed by Suharto's New Order government.

\section{The Setting}

Like the preceding elections of 1971 and 1977, the 1982 election would focus on membership of the national parliament, although local provincial and municipal legislative bodies would be chosen at the same time. Three official choices were slated numerically: 1) PPP (Partai Persatuan Pembangunan), the Muslim "United Development Party"; 2) Golkar (Golongan Karya), the Suharto government's socalled "Functional Group"; and 3) PDI (Partai Demokrasi Indonesia), the "Indonesian Democratic Party," a partial fusion of Sukarno revivalists and Christian politicians. There was absolutely no doubt that Golkar would win the election, just as it had in the past with 62.8 percent of the national vote in 1971 , and 62.1 percent in 1977.2

* I would like to thank Jim Siegel and Ben Anderson for their comments on an earlier draft of this article.

1. Ken Ward, The 1971 Election in Indonesia: An East Java Case Study (Clayton: Monash University Centre of Southeast Asian Studies, 1974), p. vii.

2. The real weight of these wins becomes apparent in light of the make-up of 
The immense Golkar had been engineered by the Suharto government for the 1971 general election, the first election held under the New Order government, some sixteen years after the Sukarno government had held the first general election in Indonesian history in 1955. Describing the 1971 election, Masashi Nishihara noted the new feel of a New Order election:

A comparison of these elections with those of 1955, the only other national elections held in Indonesia, would not prove very meaningful, since the two elections were held under very different circumstances. The 1955 elections saw some forty political parties and groups freely campaigning for legislative seats, while in 1971 the participating groups were limited to ten parties including the government's Golkar. The Communist Party (PKI), generally regarded as the largest party by late 1957, has been banned since 1966. The youngest voter in 1955, who would then have been 18 years old, was 34 years old in 1971, and voters between 17 and 33 years old in 1971 cast ballots for the first time in their lives.

Thus, in studying the 1971 elections, it is appropriate to emphasize the means by which the Suharto government tried to organize its electoral victory rather than the manner in which the Indonesian voter responded to the election campaign. 3

A key logic by which the Suharto regime organized its 1971 and subsequent victories is reflected in the politically ambivalent nature of the term "Golkar." Although designed to participate actively in, and "win" $\mathrm{New}$ Order Elections, Golkar was not defined as a "political party," but rather as a "group" (golongan) of "functional occupations" (karya). Under the long reach of its "protective" banyan tree emblem, Golkar encompassed a wide range of civil servant functionaries. Implicitly, however, Golkar commanded a large majority of New Order voter-subjects who felt obliged to identify with their local ruling administrators, hence the Suharto government, and in turn, the Indonesian Armed Forces that support it. At bottom, a vote for Golkar appeared to be a vote for "government" itself.

In the 1971 election design, nine officially designated "political parties" (partai politik) were slated to run against Golkar. At that time, however, the word "politik" was marked by a sinister, and for many, frightening tonality acquired following the hundreds of thousands of "political" killings--expressed in New Order terms as "anti/pro PKI"-which accompanied Suharto's rise to power in 1965-66. Thus, the 1971 "political parties" were suspects cast as potential threats to the new national stability. Promoted as a commanding alternative to party politics, Golkar emerged, by definition, as the apolitical choice.

the national parliament (DPR). Leo Suryadinata notes: "The grip on Indonesian politics by the military-dominated government can be seen in the composition of the DPR. . . The national DPR consisted of 460 members, 360 of which were elected, while 100 were appointed (25 civilians and 75 military) by the government (President). The structure clearly favoured the government." Leo Suryadinata, Political Parties and the 1982 General Election in Indonesia (Singapore: Institute of Southeast Asian Studies, 1982), p. 7. Of the total 460 (elected and appointed) seats, the military government controlled 327 in 1971 and 332 in 1977 . All voting tabulations in this article are taken from Suryadinata.

3. Masashi Nishihara, Golkar and the Indonesian Elections of 1971 (Ithaca: Cornell Modern Indonesia Project, 1972), p. 3. 
The force of the New Order's "apolitical" politics was expressed in a series of campaign regulations prepared for the 1971 election. Under PP 1/1971, criticism of the government or its officials was banned. Moreover, any "discrediting" of organizations, including political groups, was strictly forbidden. Writing on the 1971 election in East Java, Ken Ward summed up the situation: "The whole burden of these regulations was that the election and the campaign would be held in an absolutely security-guaranteed, indeed antiseptic atmosphere, devoid of political content, of political or ideological dispute, and even of social or political differences." 4 A correlative set of regulations fell directly on the candidates themselves. Thorough screening procedures, administered both by local committees and by the Kopkamtib (Command of the Operation for the Restoration of Security and Order, a security body established by Suharto in 1965), determined a candidate's acceptability by disqualifying those deemed a threat to national security. Again, Ward summed up:

for hundreds and thousands of East Javanese . . . Golkar was almost the only organization guaranteeing prestige in official society, the chance of a political career (albeit under military guidance in an avowedly apolitical atmosphere), and offered the prospect of remunerative employment. At best, joining Golkar could bring access to the sympathetic ear of the Kodim commander; at worst, remaining in a party, or joining one, brought official displeasure and suspicion. 5

By 1977, the political party structure had again been altered by the Suharto government, which consolidated and reduced the nine formal parties of 1971 to two: PPP, the new officially approved Muslim party, and PDI, a potentially nostalgic, Sukarno-tinged party. Substantially domesticated by New Order political strategy, the two parties now functioned as a convenient reminder of all that New Order security was fabricated against: the state politics of "Islam" on the one hand, and the rhetorics of "Revolution" on the other. Positioned as choice Number Two on the ballots, Golkar appeared all the more a "neutral" alternative to the "extremist" tendencies of party politics. The successful staging of the 1977 election demonstrated that the Suharto government was anything but the "ephemeral thing" that Ward and many other analysts had anticipated during the open protests of the mid 1970s. Rather than undermine New Order solidity, the 1974 demonstrations provided yet another opportunity for the Suharto regime to display its commitment to security. The 1977 election brought this home by presenting a nationwide public event in which New Order security was, in effect, commemorated.

The 1982 general election fell right on schedule, exactly five years after the 1977 event was completed. The youngest voters of 1955 were now approaching their fifties, while students of the activist "'66 Generation" were drifting into their forties. Juxtaposed to the noticeable youth of most campaigners, these updated calculations assumed a new significance in 1982. For the majority of voters, the now familiar Pemilu (from Pemilihan Umum, General Election) was customarily won by Golkar and termed a sukses (literally, success). For many, Golkar's sukses(es) formed the whole of their electoral memory, all the way back

4. Ward, 1971 Elections in Indonesia, p. 14. My summary of the 1971 election owes much to Ken Ward's perceptive analysis.

5. Ibid., p. 84 . 
to childhood. During the 1971 election, the strategy behind the Suharto regime's transformation of the noun "sukses" into the transitive verb mensuksèskan ("to success") was still visible: the government's campaign command to Mensukseskan Pemilu meant to "Golkar" the election. However, by 1982 "sukses" had a history; victory was assumed. Now Mensukseskan Pemilu meant, in a twisted sense, to "secure" a victory already scored. 8 If Golkar meant "government," Golkar sukses meant "election." Government officials matter-of-factly noted that elections were held regularly "in order that the requirements of 'demokrasi' be fulfilled."

Perhaps due to Pemilu's almost ceremonial regularity, the government felt moved to declare the 1982 general election a "Pésta Démokrasi," a striking phrase translated by the foreign press as "Festival of Democracy." Strange as this translation may sound, "Pesta Demokrasi" is in fact an even stranger image for democratic elections. Rather than refer to "festival" (which carries its own highly celebratory, at times carnivalesque, semantic force), the Indonesianespecially Central Javanese Indonesian--term "pesta" usually refers to formal receptions regularly tied to public ceremonies and domestic rituals. Thus, the ideal 1982 election scene envisioned by the New Order government was that of, say, a Javanese-Indonesian ceremonial wedding reception where guests are ushered to socially predesignated seats to act as entertained but quiet witnesses for an event executed with close to perfect predictability-as well as, perhaps, $a$ hint of festivity. Nearly untranslatable, "Pesta Demokrasi" sounds a little like a "Formal Democracy Reception."

It $w$ as in this spirit that President Suharto addressed the opening ceremonies of the National Conference of Governors, District Chiefs, and Mayors in February 1981 in preparation for Pemilu 82 : "We must perceive the General Election as a grand 'pesta demokrasi,' as a use of democratic rights which is responsible and absolutely not turned into something that makes us tense and holds us in its clutches."7 By March 1982, the official formula, "We must perceive the General Election as a pesta demokrasi," had been repeated religiously throughout the New Order bureaucracy, down to the lowest level. Central Javanese administrators felt it their duty to act as responsible local hosts for what came to be thought of as an upacara nasional, a national rite. One unusually enthusiastic low-ranking Solonese official even beamed in anticipation of what he imagined would be an "upacara kolosal."

From the very beginning of the 1982 campaigns in Solo, Golkar's posters were virtually indistinguishable from government billboards calling on the public to Mensukseskan Pemilu '82. Golkar handouts cautioned that the election was not a goal in itself, but rather "an education in national politics." In front of all local administrative offices stood a Golkar placard which read:

The Victory of Golkar guarantees material and spiritual happiness.

The Golkar family deeply respects Religion and a belief in God.

The Golkar family is always disciplined, orderly, and polite.

The Form that best fits workers, businessmen, and people of culture is Golkar.

Golkar honors the sacrifices of national Heroes.

6. I am indebted to Ben Anderson for the "secure" suggestion.

7. Lembaga Pemilihan Umum, Buku Pelengkap II Pemilihan Umum 1982 (Jakarta, 1983), pp. 39-40. 
With these five themes, its standard proclamations on the good of Development (Pembangunan) and the need for Security (Keamanan), its regal emblem of the protective banyan tree, and its invitation to join in the Pesta Demokrasi, Golkar controlled most of Solo's visible space.

Toward the end of March, how ever, signs of the two "political parties" began to emerge with new posters, many in Javanese rather than Indonesian. Menyang Mekah Munggah Kaji, Nyoblos KA'BAH Tentreming Ati (Go to Mecca and Make the Haj, Vote KA'BAH [Mecca's shrine and PPP's emblem] for Peace at Heart). Aku emoh dipekso (I ain't gonna be forced) captioned a comic-book hero choosing PDI. Lines became more hard hitting as "anticorruption" slogans attached to PPP and PDI posters implicitly stuck to Suharto with his Golkar. Soon, poster politics gave way to graffiti warfare. "Hotel Banteng"-the banthèng or wild bull was PDI's emblem--appeared above one underpass used for shelter by homeless itinerants, "Ka'bah Station" above another. Solo had become a rising sea of political script.

Because the campaign posters appeared around entrances of the hundreds of small roads and alleys which open into Solo's neighborhood life, they seemed to identify a neighborhood as, say, PDI; but this identification was actually superfluous. Most everyone already knew local voting histories: the few massive neighborhoods of the powerful mosques, old textile centers, and "Arab" quarters were PPP; the poorest neighborhoods at the city's edge, particularly those near the bus terminal, garbage dump, and river bank, as well as a few Christian blocks went PDI; and all the rest was Golkar.

The place for campaign life, for real political movement, was not the neighborhood, but the streets, especially Solo's long main street, slamet Riyadi. Here, campaign billboards competed with one another, alongside Indonesian ad signs and Kung Fu and Charles Bronson banners featuring movies like Love Massacre, to form the graphic background for campaign action. By late March, every afternoon attracted well over a thousand demufflered $100 \mathrm{ce}$ Yamahas and Suzukis that screamed past neighborhoods in tight formations of a dozen or so, sometimes alone daredeviling in and out of traffic, occasionally en masse. All revved their engines in cadence, 1-2-123-, as if sounding the designated campaign numbers in composite sequence. All were headed for slamet Riyadi to drag its legendary length, spin off at top speed through side streets towards the city's edge, and regroup to do it again. "Ah, it's the campaign!" retorted an old man with a sort of bemused complacency. The sound alone signaled politics; something was in gear.

\section{The Events}

Sunday April 4 brought Solo its first full-scale political rally in a campaign schedule which allotted one Sunday to each of the parties during the first three weeks of April. The final weekend was saved for three successive days of campaigning packed back-to-back just before the Minggu Tenang (Week of Quiet) which directly preceded the May 4 election day. For the opening rally slamet Riyadi was lined with parked becak positioned as a temporary and overstuffed grandstand, with kids on shoulders straining to see what would happen, and with hawkers making a quick killing (before the rains set in) on soft drinks, toys that move, and an arsenal of noisemakers. As the first group of this Sunday's Golkar cycles raced past, riders standing and displaying two fingers for Number Two as well as for Victory, police pressed the spectators back. Then came open trucks, the large kind used for transporting sugar cane, livestock, or army troops, one 
after another hauling more Golkar supporters, banners, and loudspeakers proclaiming, in so many words, Development. Small army vans took position at each major intersection. The sheer noise and pressure of crowding recalled the annual maleman (night fair) in Solo; but the fact that this enormous "night fair" was taking place in broad daylight gave it an uneasy feel, as did the overriding sense that all were watching as if anticipating something that might happen.

Without warning, PPP trucks appeared, carrying amplified Hidup $\mathrm{Ka}$ 'bah (Long Live Ka'bah) and index fingers pointed skyward for Number One and His supremacy. There had been a campaign scheduling mix-up which placed both Golkar and PPP on Slamet Riyadi, face to face. As if summoned by the first drops of rain, army troops and police moved quickly towards the crowds of spectators, the great bulk of whom, equally fast, split. Within minutes several truckloads of Golkar men emptied into the streets, hurling threats, then rocks at the PPP marchers who responded, though clearly outnumbered. The brief clash was almost over with PPP scattering, when a large group of motorcyclists, this time PDI, arrived and joined PPP. Now there were real blows, wounding some, several probably seriously. The remaining Golkar men ran for refuge in the luxury class Hotel Cakra. As an ambulance pulled up, PPP trucks and PDI cycles took off. Several hundred reassembled spectators, many of whom had joined in behind the PPP-PDI side just moments ago, stood in the street and stared at a pair of armed soldiers posed on the corner nearest the hotel. One of the army men began fiddling with his rifle, then shouted hoarsely, almost as if threatened: "What are you looking at? The street is for going somewhere. Go!" That is all it took; the crowd did not disobey.

By early the next morning most of Solo had heard of the peristiwa, the incident, the Hotel Cakra Incident. A Golkar cycle had been hit by a PPP cycle and this triggered a clash which left three PDI followers dead, it was said, in front of Hotel Cakra. If it had not rained, Solo would have ignited. This was the rumor that swept through the warung, the hundreds of tiny food stalls and gossip stands which appear, each with its own lamp-glow attraction, along the city streets and dim alleyways of Solo at night. This rumor triggered others, in much the same way that the normally insignificant motorcycle collision in front of Hotel Cakra was said to have set off what followed. Thus, it was added that on the night of March 27, PPP headquarters in nearby Yogya were attacked by a group of armed Golkar men. One of the five PPP officials inside could not escape and was said to have been hacked up-his nose and legs cut off and the remains thrown into a well. Police reportedly ordered that the body be buried immediately, to prevent stories. The next day, memorial services had been held for the PPP victim at a local mosque in Yogya; that night PPP followers ripped down hundreds of Golkar campaign posters. This story of mass retaliation recalled, in turn, other stories, of ten including the well-known March 18 Lapangan Banteng Incident in Jakarta when an apparent conflict between PPP campaigners and those of Golkar at a central Golkar rally touched off an incident which destroyed cars, buses, shops, and offices, ending in over three hundred arrests. If this had occurred in Solo, it was figured, it would have spread, "like fire," all over Java. 8

From the warung stories there emerged one phrase, one Javanese word, which repeatedly recalled the sound of persons rushing forward, drawn into what might

8. For Tempo's version of the Yogya story, see its April 3, 1982 issue, p. 14. For the Lapangan Banteng report, see Tempo, March 27, 1982, pp. 12-15; April 3, 1982, pp. 12-13; and April 10, 1982, pp. 12-13. Also see below, pp. 15-16. 
later become an incident: grubyug, or better yet, gumrubyug, that unmistakable thunder of crowds on the move, that uncertain point when the attractive everyday pleasure of ikut-ikutan, of "just tagging along" on a Saturday night escapade, for instance, gathers an irreversible momentum and moves toward an obsession all its own. By the end of the first campaign week in April, this haunting, audible sense of Javanese political movement was rumored nightly in almost every street gossip spot in Solo.

The following Sunday, April 11, was clearly PDI's; there would be no campaign scheduling mix-up this time. At a central point on Slamet Riyadi, almost in front of Hotel Cakra, a great reviewing stand was constructed for the day's visiting PDI national officials. The stand's rigid scaffold structure, erected on a spot just a stone's throw from the previous Sunday's Cakra Incident, appeared to counter grubyug politics. For above all else, the imposing stand did not move.

As before, truckloads of campaigners flanked by loose squads of motorcycles roared past. But this Sunday, there were no breaks in the noisy political trafficking on Slamet Riyadi. The army and police were outnumbered by PDI youth who joined in pushing back the enormous crowds of spectators pressed along the six mile campaign route. After an hour, an amplified and unnervingly familiar sound emerged from the noise:

It is written in the book Ramayana that in the country of Northern Kuru there was no heat which was too hot, no cold too cold, no sweetness too sweet, no bitterness too bitter. Everything was calm, oh so calm. No hot, no cold, no darkness, no shining light. "Like unto the divine coolness and tranquility that cometh from a blessed cycle of heavenly waters." In the book Ramayana it was thus stated. Hmm. - . But a country like this cannot become a Great Country because there is no... "UP and DOWN, UP and DOWN!" The Struggle is not there. All is cool and calm. Enjoy but don't enjoy too much; and don't be too sad. That's it, calm, calm in Northern Kuru. Do you want to become a People like that? No! We don't want to become a People like that. We want to become One People, forged together by the conditions, every day. Forged, almost crushed to bits. Rise up again! Forged, almost crushed to bits. Rise up again!

The voice, blasting from a slow-moving becak through a well-distorted loudspeaker like the kind used for daily mobile movie ads, was that of the late Sukarno. In this 1982 campaign parade, the old taped speech recalled the restless, spirited zaman politik, the so-called "political era" when a plethora of political parties campaigned vigorously in 1955. Flanked by a familiar large portrait of Indonesia's first president, the speech also brought to mind "The Struggle" and the hopeful "zaman Revolusi" when Indonesia's political independence was proclaimed in 1945. But indirectly, the impassioned "political" sound of the speech recalled the threatening sense that "politik" has acquired since 1965. "Politik" is something to be marked out and then observed, from a safe, well-defined distance. The reviewing stand officials stood, applauded, and waved three fingers for PDI.

The long parade of PDI people moved slowly, taking three hours to pass. The marchers were predominantly young and male, costumed in black T-shirts, jeans, and red bandanna headbands. But most also wore some reference to the zaman Revolusi: smudged charcoal faces with casually dangling cigarettes and "tough" 
glances; "bloody" gauze head bandages; Red-and-White Indonesian flag cloaks; glassless black-framed "glasses" of the bespectacled "45 Generation"; and shirts printed with a black silhouette of Bung Karno or Demokrasi. Within the ranks of these young "old fighters" were parts of "modern" military outfits--a white leather gunless holster here, a mismatched uniform there-scattered in a way suggesting "military" rather than identifying a specific unit. Also within the ranks were "traditional" powerful characters costumed in "magical" black turbans, clip-on beards, and temporary tattoos, or shouldering thirteen-foot boa constrictors, or stubbornly dressed in the old-fashioned coolie outfit of "peasants." This grand procession of quotations was indeed, as one PPP spectator somewhat cynically quipped, "a really good parade." Nevertheless, the unfortunate sight of all this casual revolutionary camaraderie and traditional intimacy, character after character each just out of arm's reach from the next, trudging along in a more or less orderly manner, created the queer impression of a perfectly disconnected "solidarity."

The primary aim of the organizers was simply that the parade keep moving. For a brief moment, a spirited reyog "trance dance" troupe stopped in front of the reviewing stand and quickened the tempo of its enticing rhythms. Lured by the attraction of the masked dancers, two boys sprang from the crowd to join in. In a second, nervous reviewing-stand officials signaled the troupe to move on and make room for those that followed. Throughout the PDI's afternoon all that followed, of course, were more followers, marching along behind. The familiar accumulative logic of ikut-ikutan was bracketed: at no other point did spectators rush to join the following, nor did they cheer on the procession which seemed to move along regularly on its own slow accord. More remarkable was the total absence of attempts from PDI marchers to attract new followers. There were no invitations to the crowd to join PDI's ranks and no signs displaying possible campaign issues-the cost of education, uneven distribution of wealth, prevalence of corruption-which might somehow persuade voters. After following the parade (as, in fact, few did) to its destination, the huge grassy square (alun-alun) which opens out in front of both the central mosque and the old Solonese palace, one found no inspiring political speakers, no speakers at all, just tired marchers about to head off home through back streets. In front of the reviewing stand on Slamet Riyadi, it was as if this procession had come from nowhere and was going nowhere, but simply provided a temporary focus for those gazing from the street's edge, as if waiting for something to happen. But nothing really happened--no accidents, no incidents--and the PDI officials were obviously proud.

Although the April 11 parade had gone smoothly, the very next day the government ordered that the central section of Slamet Riyadi be strictly off-limits for all PPP and PDI campaigning. This ban covered not only mass parades, but even the individual display of anything that could be read as a sign of partai politik. The rationale for the ban was a legal convenience, a clause in Election Regulations that prohibited campaigning near the headquarters of one's opposition. Since the Golkar office was right on Slamet Riyadi, that was that. Implicit in the rationale was the logic that Golkar was not actually "political" and thus no threat to order in the streets. Both PDI and PPP were furious, and once again slamet Riyadi became a source of news and related rumors.

One story in particular preoccupied many warung during the evenings of the third week in April. It had been in the air for several weeks and reported 
briefly in the nationally prestigious Tempo magazine on April 3.9 Perhaps because the story's protagonist was a notoriously brutal Solonese underworld figure, or perhaps because the story itself had already seen the light of print, it had not been talked about much. But the almost simultaneous suspension of Tempo's publishing rights and ban on Slamet Riyadi PPP/PDI campaigns suggested, it was argued, that something was happening in Solo, that Tempo had begun to report it, and that this was the story behind it: Solo's "Silir Incident."

In the early hours of March 26, so the story went, four truckloads of AMPI men (paramilitary "youth" squads organized by Golkar) pulled up at a small warung filled with a dozen local PDI followers. The AMPI contingent was led by Usi, a regionally known hood, who was manager of Solo's most extensive and government-supported prostitution quarter called Silir. He was also an all-round muscle man for Golkar. In less than a minute Usi singled out and stabbed one of the PDI men who, almost as fast, succeeded in fleeing with his life. Usi pursued and the PDI man made it to familiar territory, the maze of alleys and tight neighborhoods attached to the old palace's southern walls. But here someone screamed "thief," and the poor man was almost clubbed to death by his eager neighbors before he could identify himself. The next morning, more than 3,000 PDI followers marched to a local police command post and demanded immediate official action against AMPI. Because an official decision was not offered, that night trucks carrying hundreds of PDI men descended on Usi's rather luxurious house in Silir, destroyed AMPI cars, and took over the house; but Usi was gone. At this point one middle-aged PDI organizer, a Solonese highly regarded for a talent at smooth easy-to-listen-to talk which almost equaled his talent at split-second violence, slowly persuaded the crowd that Usi had been arrested, that it was best to go home.

Behind the Silir story was an explosive logic: Usi was "Chinese." 10 This single detail made automatic sense of the mass movement against Usi, both that morning at the command post-when else could 3,000 march on it and not only get away with it, but receive a silent go-ahead to boot-and then again, that night in Silir. In warung conversations, the incident recalled the much celebrated Solo Incident of November 1980 when a minor traffic bump involving a bicyclist and a "Chinese" pedestrian touched off a series of violent mass actions aimed at local "Chinese" Java. 11 More than any other event in Solo's recent history, the 1980 Solo Incident was cited during campaign rumorings to demonstrate vividly not so much Solo's anti-"Chinese" attitude, but the remarkable, far-reaching forces that could be set off by an accident, even a small accident, when it occurs in Solo. This "Chinese" connection gave the Silir Incident a peculiar potency not because it raised issues concerning local "Chinese" business practices--indeed, Silir was immensely popular-but simply because it linked the current incident with the 1980 violence. The terms of the incident in Silir remained patently political: PDI

9. Tempo, April 3, 1982, pp. 13-14. The story's title reads: "Silir pun Ikut Terguncang."

10. The quotation-marked "Chinese" refers to cina, the dominant, of ten pejorative, Indonesian term for Indonesians and resident aliens of Chinese descent.

11. When the "Solo Incident" was told as a story, it usually began with the accident. Accounts of the incident can be found in P. Bambang siswoyo, Huru Hara Solo Semarang (Indonesia: Bakti Pertiwi, 1981); and Tempo, December 13,1980 , pp. 12-14, and 54-58. 
versus Golkar. Usi happened to be the pivotal figure in a peculiar logic of accidents. It was as if the traffic accident which triggered the 1980 Solo incident coincided with the accidents claimed to trigger 1982 campaign incidents like the one in front of Hotel Cakra. Most likely this logical coincidence, reinforced by the supplementary coincidence of the Tempo and Slamet Riyadi bans, created the compelling feeling that an inevitably uncontrollable moment was close at hand in the Solo campaigns. The warung buzzed with references to a sa'at, an approaching "moment when...." Whenever a campaign incident occurred without touching off a mass response like that of the 1980 Solo Incident, one often heard the phrase, durung sa'ate-it wasn't "time" yet, its "moment" had yet to come.

Sunday April 18 officially belonged to PPP. Again, truckloads of PPP followers flanked by motorcyclists roared the streets. However, since Slamet Riyadi was now off-limits, there was no possibility that PPP's campaign would dominate the city that way PDI had the previous Sunday. Perhaps because of this, there emerged a point of convergence, a destination: Pasar Kliwon, an old market area at the center of Solo's most populous "Arab" quarter and home of one of the city's more powerful mosques. The traffic flow itself produced a parade radically different from PDI's. Thousands of mobile PPP supporters, with crowds of spectators following along, poured into a bottleneck that becomes the main street through Pasar Kliwon. All of the energy that high-speed campaigning carries suddenly was transformed into a mass so dense that it barely moved. There were no costumes, police, performers, or reviewing stands; in their place, shouts of "Hidup $\mathrm{Ka}$ 'bah" and "Allahu Akbar" echoed all around. The boundary between the street and its edges, between followers and spectators, collapsed jubilantly. Whole families leaned out of shuttered windows in the old secondstory apartments that line the streets and poured religious bucketfuls of cooling water on those below. That morning there had been keynote speeches by PPP leaders from Jakarta. 12 By afternoon, Pasar Kliwon itself seemed to embody PPP when for the first, and only, time during the long 1982 campaigning in Solo, an entire community was somehow on the move.

Sunday April 25 and Monday the 26 presented PDI and PPP with their last official days of campaigning. With Slamet Riyadi still off bounds and all major parading past, the political parties had no alternative but to do what they had been doing all of April: race the streets in open trucks and tight clusters of motorcycles, more furiously than ever. Occasionally the noise cut across Slamet Riyadi, taunting the army and police in position there. Often it moved so fast it was impossible to make out from the blur which party was represented, if any at all. Often too, a lone cyclist could be spotted wearing each of the three representative numbers, one after the other, or all at once. Now the noise could even be heard late at night. 13 The trucks of followers and especially the motorcyclists seemed to be bypassing politics; but, in fact, this represented a state of affairs all the more politically radical. People began to remark that this was a Saturday

12. Among the speakers was Ridwan Saidi who advised the audience: "in the Week of Quiet ahead, a lot of tricky 'spooks' will roam about, making power plays and coercing the populace. When the spooks appear and go into action, just scream: Thief! Thief!" Pelita, April 24, 1982.

13. This was in spite of a ban-in effect since April 6-on night campaigns in Central Java. 
night affair (malem Minggon) which had exceeded itself because it was full of émosi (dramatic anger, emotionality). Why emosi? Because this was politik! The 100 ce tempest became a peculiarly political omen that questioned the reigning order by unquestionably disturbing the peace.

The response of the army and police to the illegal night campaign movement was the same as on late Saturday nights when, seasonally, Slamet Riyadi became an illicit motorcycle drag strip: the police completely ignored the cyclists. Instead, they chased back the groups, of ten crowds, of onlookers accumulating first on one corner, then another, in episodic kucingan (cat and mouse). Reasoning that the cyclists were motivated by a trance-like control induced by the cheers of spectators, the Solonese police held the crowds, not the cyclists themselves, responsible. Nevertheless, given the sheer numbers of cyclists roaring through the streets of Solo in April 1982, the police did not really expect to separate the spectators from such an attraction. Thus, throughout the campaigns, crowds of onlookers represented a double threat to the police, army, and ultimately, the New Order government. On the one hand, crowds were thought to be the active motivation behind a political noise which drove the cyclists on. On the other, crowds seemed always to be waiting for the sound of an incident that could be followed, gumrubyug. During the last week of April, a dozen or so army troops and police were stationed at every major intersection along Slamet Riyadi. They were conspicuously not watching campaign trucks and cycles sail past from all directions.

On the final campaign day, April 27, Golkar was slated to hold its last grand city-wide parade. For it Slamet Riyadi was not off bounds. Just before the parade, Golkar officials circulated fliers with cautionary reminders for their followers: "Watch out for certain groups fabricating issues meant to sabotage the election and discredit Golkar; look out for subversives disguised as Golkar; report all threats to Golkar, immediately." Now, large convoys of army troops joined the police already positioned on Slamet Riyadi. Solo's few ambulances and fire trucks, along with a sizeable collection of other official city vehicles (including several dump trucks), stood ready at the intersections.

The motoreyclists and marchers who led the parade were noticeably different from those of the PDI and PPP movements. Golkar's T-shirt uniforms were spanking new, white, and carried along by pairs of spotless sneakers, thousands, padding down Slamet Riyadi in muffled triumph. There was little precision but extreme order in these ranks of civil servant-plus-families. They carried a banner which proclaimed Parade of Development and announced the floats that followed. Large flow charts designed to demonstrate the Fertile Society's graphic success passed by, as did Mitsubishi minibus-loads of women-Golkar Women: Pillars of the State. Golkar youth in new pickups displayed placards with formulaic commands, the same ones that dominate daily headlines: "We must (Kita harus! Haruslah!) . . . preserve, conserve, implant, improve, etc., the culture, the order, the spirit, the character, etc.!" A car-length cardboard pencil pointed out that Education is Important. A papier-mache mosque appeared with women in pious costume and a sign: Golkar Respects All Religions, Especially Islam. A traditional wedding with ceremony-in-progress followed: Golkar Respects Traditional Customs. Papier-mache schools, electric plants, ideal hospitals, and waste-disposal systems passed by, too, along with all the other departments dutifully representing Development as well as Father Development, Suharto himself. Except for a couple of clowns from Solo's failing wayang wong troupe, there was little in the procession that really excited 
the spectators. Not until torrential rains intervened was there much action, as army troops, police, and Golkar officials rushed to the aid of paper floats in distress. An entire Sugar Factory began to dissolve, then split leng thwise, and finally just slid off into the street behind the truck that had been carrying it. Within hours, the 1982 campaigns came to an official end in Solo, rains or no rains.

That night, the eve of the Week of Quiet, the rains cleared and campaigners were busy again; but now they were tearing down the thousands of posters that had accumulated everywhere, from neighborhood WC's to Slamet Riyadi billboards, over the six-week campaign schedule. This political clean-up (pembersihan) was carried out with unusual enthusiasm. One energetic group of men followed another in removing all signs of the campaigns, all traces of politik. By morning, many posters had disappeared as miraculously fast as they had first appeared in mid-March. In their place, the theme tenang (quiet, calm) filled newspapers:

Today we enter into the Week of Quiet after enduring a 45-day campaign period and before Election Day on May 4.

The Week of Quiet is meant to calm ourselves and clear the air so that we can calmly and with a cool head execute the national election.

Perhaps during the Week of Quiet we can begin an effort to neutral-ize [menetralisir] and then eradicate all of the results from the excessive acts [ekses-ekses] which occurred during the campaigning, so that no mutual hate or grudges arise, 14

On the surface, Solo was, in fact, calm; but at night, new rumors of violence spread during what became a very gossipy week of quiet. The prime story concerned the last week of the campaigns. On April 22 a PDI man wearing his party's emblem stopped for gasoline at a station on off-limits Slamet Riyadi near the Golkar headquarters. He was confronted and shot dead, it was said, by an army man who claimed to be protecting the headquarters from arson. During the funeral for the victim the next day, PDI pall bearers spotted an army man aggressively approaching the procession. It was rumored that the crowd turned on the man and chased him down an alley where he was hacked to death with hand sickles. This, it was reckoned, accounted for the heavy turnout of the army at the final Golkar parade on the $27 \mathrm{th}$. Scores of other rumored incidents followed: stories of collisions, threats, and confrontations. But just before election day, a final, brief rumor circulated. Its very simplicity signaled an end to all stories: sa'ate wis liwat, the "moment" had passed.

Except for the occasional sound of army trucks, on election day the streets of Solo were absolutely still. As one newspaper reported, even the WTS, the Women of Damaged Morals, were not to be found. It was of ten remarked that the vacated city recalled the annual Lebaran ritual holiday when all markets are closed and millions of Indonesians have returned to their village homes at the very end of the Muslim fasting month, to beg forgiveness from elders and social superiors. Like Lebaran, too, was the scene within neighborhoods where small groups of people, mostly families, were dressed up and strolling to and from local destinations. At the 869 polling stations scattered throughout Solo, a steady and controlled traffic of voters flowed in and out, past army troops positioned at each

14. Kompas, April 29, 1982. 
entrance. Inside, men and women voters customarily divided and sat on opposite sides of the room, chatting quietly, as if this were a traditional ritual reception. With the regularity of an Indonesian bank or apothecary, names were called and the summoned voter entered a cloaked booth to nyoblos (pierce) one of the three party emblems on the paper ballot, before slipping it into the locked ballot box. By 2 p.m. the voting was finished. Although officially encouraged, very few voters stayed on to watch the ballot-counting process; the day's orderliness itself seemed to indicate yet another clear victory for the government choice. In the end, Golkar claimed 64.3 percent of the vote nationwide. 15

More remarkable than the size of Golkar's victory, was its uncanny regularity. In the three national elections sponsored by the New Order over the eleven years from 1971 to 1982, Golkar's national tally has varied only two percent. But most remarkable of all, particularly in light of the numerous grubyug movements, rumors of incidents, and real expectations which grew at a fantastic rate throughout April right up until election eve, was the silent fact that the events of the campaign were rarely, if ever, brought up again in warung conversations. After election day, only a fool asked what had happened. Occasionally, he received in reply an "oh, seemed lively enough" or "basically, a sukses." "But the likely response was, "nothing happened, nothing at all." The anticipated moment had simply passed by: any momentum which might have been read into the April events in Solo, went unrealized. To the extent that the election itself recalled the campaign anticipations, even it too was soon forgotten. From the streetside perspective of the warung, by the end of May it was as if the whole business had just never happened.

\section{The Aftermath}

Although warung conversations had turned to other topics, Pemilu '82 still preoccupied government administrators as well as the press in the weeks after the election. Official ballot counts were calculated and recalculated with apparent precision and released with deliberate slowness. This was done, according to one Solonese administrator, not because the technology for quick calculation was missing, but because the government wanted to protect the masses from the possible "shock" of a sudden surprise. Such a shock, it was maintained, might start people talking again.

While the exact figures of Golkar's success were being registered, local government officials focused their attention on the final ceremonies of the long election period. During the week or so that followed election day, syukuran-rites devoted to expressing thanks to God and all others involved in the successful completion of a task, usually a ritual task-were held by most administrative levels of government, from top to bottom. Thus, as the Indonesian newspaper Sinar Harapan reported: on May 8 at Solo's city hall

there took place a syukuran and "sungsuman" ... because the Pemilu had taken place in an orderly and smooth fashion. Mayor Sukatmo

15. PPP received 27.8 and PDI 7.9 percent nationwide, down from 29.3 and 8.6 percent, respectively, in 1977. In the 1982 DPR, the military government controlled 342 of 460 seats. PPP gained 94 and PDI 24 seats, down from 99 and 29 in 1977. In Solo, Golkar claimed 55.5 percent of the vote, PPP 17.8, and PDI 26.8 percent. Golkar's increase from 51.2 percent in $1977 \mathrm{was}$ at the expense of PDI which fell from 31.5 percent in 1977. Suryadinata, Political Parties and the 1982 General Election, pp. 76 and 80. 
explained that the Pemilu was over now and that the previously tense, heated atmosphere must be removed. . . .

Syukuran also took place in the outlying areas. The District office in Sukoharjo held one two days after election day, at the same time that the army troops assigned to that area were dismissed.

In addition, the Subdistrict head of Kartosuro, Drs. Suharto Hartoto, held a syukuran which continued with an intimate evening shared by the Political Parties, Golkar, Election officials, and army company and platoon troops. The syukuran was entertained by dancing and singing.

In neighborhoods, the syukuran were smaller, more local affairs. 18

The quotation-marked "sungsuman" (bone marrow porridge) referred the newspaper's readers to a predominantly Javanese custom usually tied to a syukuran held at the conclusion of more complex domestic rituals, like weddings, which draw heavily on the labor of neighbors and kin. Ritually consumed, the marrow porridge is meant to restore strength and knit together social fractures which may have occurred during the concluded ritual's of ten extensive preparation. In a single word, "sungsuman" reread the entire election event as an enormous, successfully completed ritual task. In mid May, after the syukuran, sungsuman, and evenings of formal "intimacy" were over, the army troops departed and "normal" life (kehidupan normal) returned to the Solo area.

In Jakarta, exactly one week after election day, Kopkamtib Chief Laksamana Sudomo summoned the chairmen of Golkar, PPP, and PDI to give ceremonial thanks to President Suharto for successfully organizing the "great task" (karya besar), Pemilu '82. Then, in a Lebaran-like gesture, each of the three chairmen "offered his deepest apologies to the entire Indonesian people for any possible excessive promotion of his respective party/group during the campaign period." 17 In return, Sudomo thanked the chairmen (whom he referred to as "contestants") for their help in making the election aman (secure), tertib (orderly), and lancar (smooth running). Finally, in a peculiar show of gratitude, the Kopkamtib Chief pinned "medals" on each of the three contestants: PPP's chairman was awarded a Golkar emblem, Golkar one of PDI, and PDI one of PPP. With this formal symbolic exchange, Pemilu was ceremonially finished.

There was, however, another part of the general Pemilu process still to be completed. At one point in the awards ceremony, PPP Chairman J. Naro commented that, although the campaign "storm" was over, there still remained a "sprinkling" of ill feelings which, if neglected, might bring on a "chronic ailment." Naro appealed to the Kopkamtib chief to act as the "doctor" on the case. Sudomo responded by placing an imaginary stethoscope to his ears; in fact, the operation was already in progress. Naro's request concerned the resolution of cases involving persons arrested during campaign disturbances. Because many of the arrested suspects were said to be PPP followers, the party chairman apparently wanted to clear his party of official responsibility and, at the same time,

16. Sinar Harapan, May 12, 1982. Syukuran were by no means limited to Solo. For the Yogya area, see Kedaulatan Rakyat, May 17, 1982. In Jakarta, Gen. Eddie Nalapraya "entertained" local Islamic officials with a syukuran. See Kompas, May 15, 1982.

17. Ibid. 
display some concern for those arrested. One week later, Sudomo issued an official statement that all "ekses-ekses" which occurred during the 1982 Pemilu, would be taken care of by the end of May.

Of the numerous 1982 campaign ekses(es) like that in front of Solo's Hotel Cakra, it was the March 18 "Lapangan Banteng Incident" in Jakarta that received the broadest national attention and most extensive official response. Its detailed coverage suggested the complex stakes contained in the notion "ekses." The incident had occurred during a massive Jakarta Golkar rally when shouts of "Hidup Golkar" suddenly were countered by hurling rocks and "Hidup Ka'bah"s. Before army reinforcements were able to disperse the crowds, Golkar's performance stage was in flames and cars, buses, and stores near the rally site were destroyed. At first, the press attributed this incident of ekses to the heat of the day, the size of the crowd, and the sway of rock star and Golkar entertainer Elvie Sukaesih's hips. Tempo concluded its initial report with: "perhaps because they were hungry, hot, disappointed, as well as frustrated that noonday, in the middle of a crowd crammed onto a field increasingly narrow. Amok, 18 This was, after all, the "campaign season" (musim kampanye), a stormy time of periodic politik when crowds of people are easily carried away. Of the 318 arrested, mostly school kids, 274 were released because they were, in Sudomo's words, just "ikut-ikutan"-just following the others, tagging along.

While the ikut-ikutan rationale initially made sense of the incident, the fact that forty or so suspects were still under arrest raised new questions: were they somehow behind the incident, or were they themselves manipulated by an invisible character in back of it all? In short, was there a "dhalang"? At follow-up press conferences with the Kopkamtib Chief, reporters pursued rumors that the incident was the result of "pemainan politik," a political game directed by someone off stage. Was PPP implicated? Sudomo answered that he had already contacted PPP's chairman, Naro, and that it was quite possible that the characters involved in the incident acted on their own, independent of party policy. Was then the government's own Minister of Information Ali Moertopo implicated? "Take pity on my good friend the Minister," responded Sudomo, holding Moertopo's hand at the press conference. 19 Thus, Tempo's second report on the incident began: "The Lapangan Banteng Incident-the turbulence during Golkar's campaign on March 18--in fact still overshadowed the campaign after two weeks. This was felt most in Jakarta: rumors spread continuously." 20

The constant rumors of a "dhalang" countered the threatening sense that the campaign crowds had moved of their own accord and were themselves the ultimate source of the Lapangan Banteng ekses. Most of the arrested--but not all-were said to be ikut-ikutan, unwitting followers of a seript possibly directed by someone else. And yet, this "someone else" was never identified; the question never grew into a full-blown incident of its own. No sooner had Sudomo opened the possibility of a dhalang, than he seemed to close it by maintaining constant contact with PPP's Naro and the government's Moertopo. Even those eventually

18. Tempo, March 27,1982 , p. 15. The report also commented: "This 'anarki' was rather different from the January 15, 1974 Incident. In that incident eight years ago, the motives and targets were clear. Anti-foreign investment, especially Japanese, anti-luxury. But in the actions taken by the angry kids this time, it was not clear what they wanted other than to destroy cars and shops" (p. 14).

19. Tempo, April 10, 1982, p. 12.

20. Ibid., April 3, 1982, p. 12. 
brought to trial were not accused of directing the disturbances. What emerged from the incident was a general sense of "ekses" which conflated the two rationales for interpreting political disturbances--the campaign season's turbulent ikut-ikutan forces on the one hand, and pemainan politik's invisible dhalang-like authority on the other. The two rationales were fitted together into a circular logic which ran more or less as follows: a stormy political climate is created by certain politically motivated characters taking advantage of a stormy political climate. With this, the charged political implications of the sense that crowds or rumors were moving on their own, were short-circuited. What was produced and what remained, unsurprisingly, was "ekses," as a natural precipitation in campaign seasons. Thus, Sudomo had already opened his Crisis Control Center (Pusat Pengadalian Krisis or Pusdalsis) "hotline" two days before the Lapangan Banteng incident. Similarly, two months later the Kopkamtib Chief could expect that all Pemilu ekses-ekses business would be "finished" by the end of May. But it was the most invisible authority of the entire election period, Suharto himself, who underscored the very regular place that cases of ekses have in New Order politics. Without interrupting his normal Pemilu silence, the off-stage president issued a brief statement through Vice President Adam Malik: "The Lapangan Banteng Incident is just an ordinary kind of case and already under control." 21

The term "ekses" had been around for some time before the 1982 election. As Ken Ward pointed out, it was one of a number of expressions developed in 1971 by Golkar's Bapilu (Body for Managing the General Election-an Ali Moertopo creation) to counter charges of Golkar steamrollering. These expressions

gained immense popularity in 1971: ekses, overacting, and less concretely, issue. An issue is an accusation or insinuation which one's opponents may make but which friends and independent onlookers would do well to disbelieve. Any violence that occurred in the form of intimidation of party members $w$ as then either an issue raised by the parties to "discredit" Golkar, or could be attributed to mere excess of zeal on the part of local activists who were given a new organization with orders to swell its membership rapidly. Such overzealousness thus produced overacting which, how ever regrettable, should not be allowed to obscure the ideals Golkar really stood for. Similarly, once any intimidation that took place was recognized to be no more than an ekses, Golkar's image need not be considered tarnished. 22

In 1982, the terms "issue" and "overacting" operated in the same way as in 1971: the former turned all criticism of Golkar into sheer slander, while the latter excused intimidation by Golkar as mere enthusiasm. The meaning of "ekses," however, had shifted. Its reach had extended to include not only Golkar overenthusiasm, but in a sense, all Pemilu overenthusiasm, especially that of the two political parties. Thus, by extension "ekses" grew to cover "politik": all campaign disturbances, be they seasonal ikut-ikutan movements or seasoned pemainan politik, came to have an almost natural feel in the increasingly familiar new order of things. As "ekses-ekses," incidents were responded to as if they were not surprising--just ordinary cases already under control. Thoroughly expected of campaign seasons, "ekses" has a sort of built-in retrospect which "takes care of thing $s^{\prime \prime}$ before their time, as if they have already happened.

21. Ibid., March 27, 1982, p. 13.

22. Ward, 1971 Elections in Indonesia, pp. 50-51. 


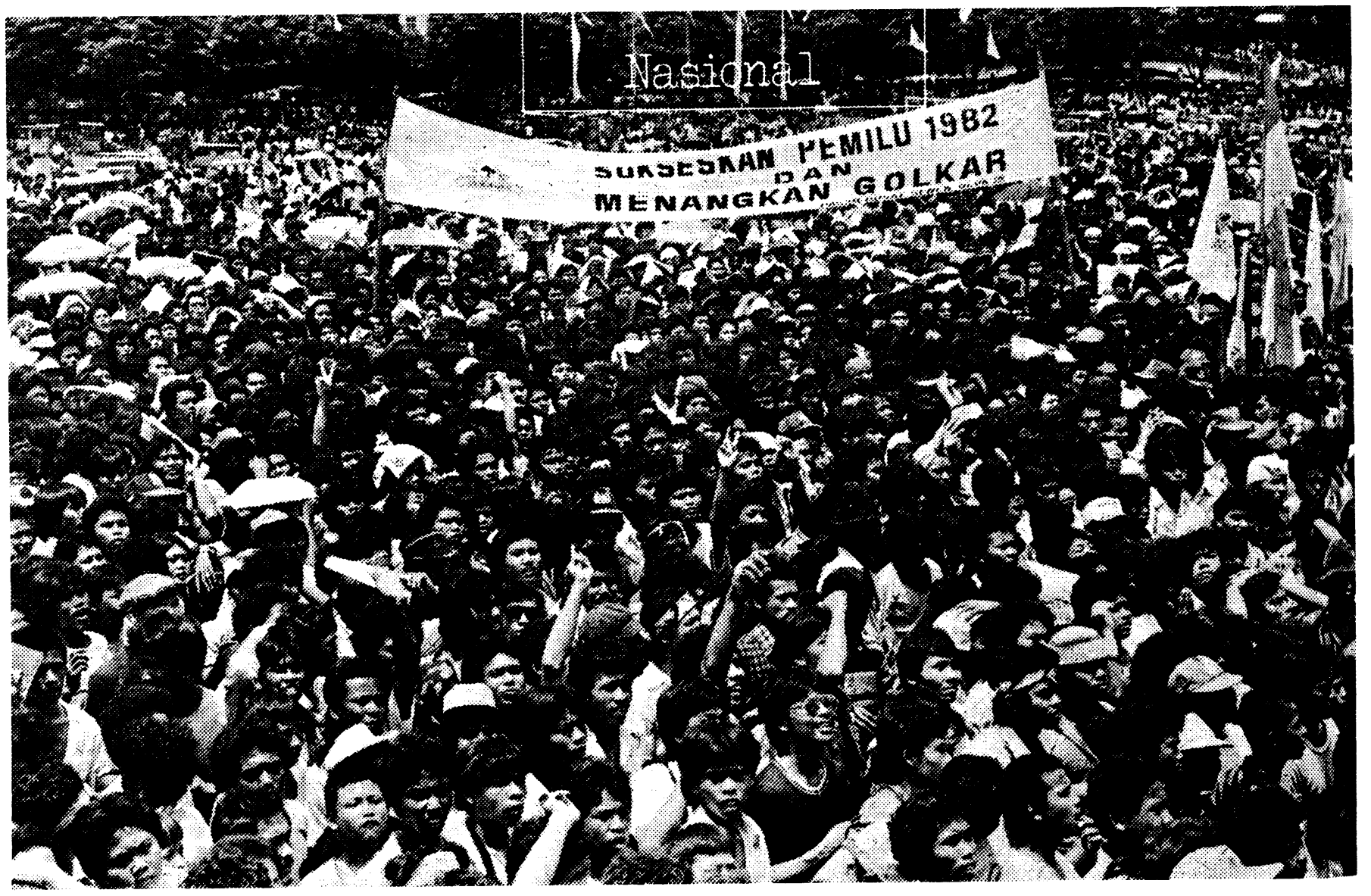

Sea of People at the Golkar Campaign Rally, Lapangan Banteng, Jakarta 
While "ekses" represents campaign incidents, it also reflects what it is not. Reporting on Golkar's April 25 final campaign parade in Jakarta, Sudomo noted that it was "performed extraordinarily well--orderly, smooth running, and very regulated. All of the participants in the parade obeyed the rules."23 He then went on to report, "regretfully," that all along the edge of the campaign route, there occurred disturbances which, when totaled, left 6 dead, 97 wounded, and 130 arrested. 24 More than any other, this last incident of the campaign period highlighted the contrast between ekses and its mirror opposite: in the face of ekses, emerges sukses. Constructed contrastively, sukses embodies all that ekses is not and appears as an ideal model of order. Confronted with disturbances along its edges, the Golkar parade was an extraordinary sukses because its participants remained undisturbed, followed the rules, and obediently exemplified discipline and order (tata tertib). But equally significant to its construction, sukses is attained by actively removing the ekses-ekses that face it. On April 25, this meant 6 dead, 97 wounded, and 130 arrested. In the process, sukses displays an ideal model for ordering. Thus, Pemilu involves more than just a calculated risk on the part of the government. In the New Order, it represents a somewhat sinister application of Clifford Geertz's classic formula for religious performance in which rituals are "not only models of what they believe, but also models for the believing of it." 25 Already apparent, victory is secured, repeatedly.

After the election, Solo's own Javanese newspaper Dharma Kandha completed its Pemilu '82 reportage with the summary headline: "Indonesian People Really Politically Conscious: GOLKAR VICTORY ABSOLUTE, POLITICAL PARTIES 'DYNAMIC.'" The story's lead-off paragraph read:

The People are amazed and exclaim, "Gee, the election was just like Lebaran; everyone together, old and young, men and women, dressed up in their very best; almost no shops, warung, or restaurants open; all freely and gladly joining in the celebration of Pemilu. It really was like a Pesta Demokrasil If one followed the campaign events, one felt insecure; but when Election Day arrived, everything really was different and ran smoothly and sukses-fully. If that's the case, now the Indonesian People really are politically conscious." 26

In its customary familial style, Dharma Kandha quoted an imaginary exclamation as if it had been heard in the "streets." If one followed the campaign events, "one felt insecure [rasane ati kaya kaya miris]." But with election day, everything really was different. "It really was like [temenan, kaya] a Pesta Demokrasi." By 1982, Pemilu had emerged as a ritual model which, with sukses, could be lived up to. In performing Pemilu, the official roles were unmistakable: Golkar's victory is absolute while the two political parties are, in a word, "dynamic."

23. Suara Karya, April 27, 1982.

24. Two days later, Sudomo gave orders to "shoot on the spot" anyone caught obstructing Pemilu '82, "especially on May 4th," election day. Sinar Harapan, April 28, 1982.

25. Clifford Geertz, The Interpretation of Culture (New York: Basic Books, 1973), p. 114.

26. Dharma Kandha, Minggu Ke-III May 1982. The Javanese headline reads: "Rakyat Indonesia Sadhar Politik Temenan: GOLKAR MENANG MUTLAK, PARPOL DINAMIS." I am grateful for Nancy Florida's suggestions on this translation and other passages in the article. 
It is not surprising that Indonesian and foreign observers of Pemilu have noted-with varying degrees of official pride, dismissive cynicism, and academic curiosity--Pemilu's ritual-like appearance. Indeed, Pemilu 182 was promoted essentially as a ritual: a Lebaran-like "Pesta Demokrasi" perceived by local administrators as a colossal domestic ceremony, a national life-cycle rite. In addition, recognizable "traditional rituals" (upacara tradisional)-syukuran and sungsuman, for example--were present, as were their equally recognizable bureaucratic counterparts--opening/closing ceremonies (upacara pembukaan/penutup). By extension, many of the events specific to Pemilu-parades, Weeks of Quiet, voting days--attained a certain ceremonial feel in 1982 because of the increasing regularity of the Pemilu process itself. Even the campaign incidents, when identified as "ekses," fit into the general formula of "sukses" by which Pemilu "82 was processed and "normal life" restored, ritually. 27 In Solo, that the campaign incidents were rarely mentioned again in warung conversations after election eve, invites such an interpretation. If the rumored incidents had been politically motivated rather than just a regular part of the Pemilu process, where, then, did all the momentum go?

The problem with this kind of ritual interpretation, however compelling it may be, is that such a reading tends to de-"politicize" its subject. What is lost by treating Pemilu as if it were a ritual, is the sense that Pemilu is political, in part, precisely because it is treated by the New Order government as a ritual. A ritual interpretation of Pemilu-by New Order officials and foreign observers alike-carries with it, willy-nilly, certain political consequences. Deeply rooted in its own conventional assumptions of cultural order, anthropological interpretation of "ritual" of ten tilts in favor of, well, sukses.

On the streets of Solo during the 1982 campaigns, one had the dramatic sense that something else, something other than the ritual restoration of order, was also at stake. Although the presence of army troops along Slamet Riyadi might have been taken as a sign of order, these "security" (keamanan) forces, in fact, signaled just the opposite, order's absence, no matter how calm (aman) everything occasionally appeared. This sense of another reality, behind or beyond calm

27. Responding to the 1977 election with "The Indonesian Elections: A National Ritual" (in Man, Meaning and History, ed. R. Schefold, J. W. Schoorl, and J. Tennekes [The Hague: Nijhoff, Verhandelingen van het Koninklijk Instituut voor Taal-, Land-, en Volkenkunde, vol. 89, 1980], pp. 179-203), anthropologist N. G. Schulte Nordholt asks: "What is the use of these elections if by all means of manipulations the results are fixed anyway?" (p. 179). Through an analysis of symbols rooted "in the 'cosmic order' of Old Java"-symbols drawn from traditional classificatory systems of pre-Hindu Javanese society, Javanese mystical beliefs on the relationship between subject and divine monarchy, and no less a monument to cosmic order than the Borobudur itself-Schulte Nordholt argues that "the national elections might be seen as 'a rite with the purpose of restoring the wholeness of chaotic society and nature.' The chaos which had become manifest in a terrifying way during the campaign had to be overcome" (p. 181). In 1982 terms: "sukses" reigns, as "ekses" is overcome. Meanwhile, in the midst of the 1982 campaigns, Far Eastern Economic Review's cover story reasoned that "religious and primordial symbols overshadow political debate." FEER, April 23, 1982, pp. 24-29. 
appearances, was sharpened during the campaign, but by no means particular to it. Tied to the New Order's concern with keamanan, is its program of pembangunan (development, construction); in a state of keamanan, pembangunan is supposed to grow. But, here too exists the sense of another reality, represented nightly on national television evening pembangunan reports, where the scenes of model neighborhoods and villages on the screen never match up with local scenes, no matter how much pembangunan appears to have been implemented. Slogans of "keamanan" and "pembangunan" are so much a part of everyday life in Solo, that the difference between what they are signs of and what they are not, is almost transparent. A sense of difference remains; it is just terribly familiar. During Pemilu, it becomes acute. Like the army keamanan troops, Golkar-Solo's April 27 pembangunan parade stood for what it was not. Not until the rains fell, did the crowds of spectators begin to show some excitement.

Probably because of their very familiarity, these differences were not what was discussed in warung during the campaign period. Instead, rumors of the numerous campaign incidents dominated conversations. Unlike Jakarta, there was little newspaper coverage of local incidents. The government is normally sensitive about news reports of "regional" incidents. However, it has been unusually cautious concerning Solo, not permitting branch offices or local editions of major newspapers in the city. Essentially all that remain are the weekly ritual pronouncements of Dharma Kandha (and its Indonesian counterpart Dharma Nyata) on the one hand, and the warung stories on the other, which combine to produce an extraordinarily split-image view of Pemilu events. Without newspapers to cover the local incidents as "ekses"--be it campaign amok or political dhalangry--rumors of incidents in Solo moved on, gathering a momentum of their own. (It was not until Tempo was banned, that its atypical coverage of the "Silir Incident" as well as the magazine itself, became a warung topic.) Like the campaign motorcycles, once in gear, the rumors too seemed to be heading somewhere, to another point beyond the political traffic on Slamet Riyadi, towards a "moment"-a sa'at.

The mid-April emergence of the notion of a "sa'at" brought with it an almost contradictory half-vision of what might lie ahead. Torn loose from the relatively domesticated identification of the Indonesian "ikut-ikutan," the Javanese "gumrubyug" movements echoed the accelerating sense of direction rumored as sa'at. Embodying the sound of erowds on the move, gumrubyug directly opposed the logic of keamanan troops whose power rests in their ability to represent what is not present--the authority of the government on the one hand, and the "secured calm" on the other. At a stand-off with gumrubyug, the troops stationed on the street corners during the last week of April seemed to have little to do other than not watch campaigners roar by. The real threat of crowds on the move is that they suddenly will turn on you. No less a keamanan trooper than Sudomo himself commented: "The climate of that 'crowd' is what made my hair turn white. -. Whether it's called Malari, Lapangan Banteng, or whatever, the 'crowd' always makes me nervous." 28 But the Javanese "gumrubyug" did not understand the significance of the English loan-trope "crowd," as it headed towards its sa'at in Solo.

The other side of the vision accompanying rumors of a sa'at, was total lack of movement: macet--stalled, stuck, conked out. For the government, "macet" represents a general fear that the bureaucracy's chain of command will break down; but more specifically, it signals the moment when economic wheels stop

28. Tempo, March 27, 1982, p. 18. Sudomo himself used the English word "crowd." 
turning. Just after the Lapangan Banteng incident, it was reported: "Jakarta Economic Activity 'Macet Total,' 240 Persons Arrested." 29 Together, this unlikely combination of threats--gumrubyug and macet-struck at the heart of New Order logic by simultaneously overriding keamanan and stalling pembangunan.

During the campaigns, it was the duty of army troops and police along the borders of parade routes to hold back the crowds of spectators, lest they gumrubyug. The job of parade officials, however, was to keep things moving. Just after the ban on Slamet Riyadi "political party" parading, the unusual official-less April 18 PPP parade slowly transformed itself into the dense mass that merged with Pasar Kliwon. But, most campaign marchers-even the April 11 PDI reyog troupe-normally followed orders to move on and avoid macet. 30 These regulated flows of campaign followers mirrored the government's ideal image of the overall Pemilu process: lancar-not speeding, not idle, but smooth running. On the streets of Solo, the ideal counterimage was the sight of a motorcycle whizzing past, its young rider reclining back, perfectly relaxed, and posed as a still-life portrait of taking it easy, santai at $100 \mathrm{kph}$.

As the "moment" seemed closer at hand, there emerged from warung rumors the peculiar sense that the smooth-running process of Pemilu would macet. This sense carried all the fascination of an enormous political traffic accident. 31 An explicitly "political" victory-that PPP or PDI would actually win-was never discussed, nor was the language of "victory" ever used. Instead, the rumors' momentum suggested that the election process itself would suddenly break down and election day would have to be bypassed. On election eve, when word spread in the warung that the "moment" has passed, it anticipated a silence in the weeks to come. Although the post-Pemilu press overflowed with reports on the election period--its results, highlights, incidents, and measures of political consciousnesswarung conversations shifted to other stories. Unmentioned was sukses; but this was not new. Absent too, were the campaign stories. Unlike the official press,

29. Jurnal Ekuin, March 20, 1982.

30. That reyog troupes--once the signal of non-"order," as well as active recruiters for PKI and PNI in 1955--should now follow orders, represents the height of domestication. In fact, for some groups orders were not even necessary, as Tempo's report on an East Jakarta PDI rally indicates: "The Ponorogo reyog group which at first had entertained the crowds, quickly stopped its deafening noise, without orders, when PDI Secretary General Sabam Sirait appeared at the podium. But the mood was still enthusiastic. . . Tempo, March 27, 1982, p. 12.

31. Long after Pemilu ' 82 was over, a crowd of spectators formed along the wide street in front of Solo's main post office. The spectators were waiting for the accidents which came, one after another in quick succession, as motorcyclists lost control and hit the pavement, swerved into other traffic, or just skidded off the road. There was an oil spill. No one attempted to warn the approaching cyclists or to stop them; that seemed to be taken care of by the oil. Even the policeman who had just dropped onto the oil with his white Honda, joined the rest of the spectators. I left, for fear of blood; but now, I doubt whether that was at stake in the scene, in spite of its inevitability. Instead, the image of all these shooting-gallery ducks going down without a single shot fired, was probably a sweetly amusing alternative to aman-tertib-lancar: a moment when the machine slips on its own oil. In this light, it is significant that the 130 spectators arrested during the April 25 Golkar parade in Jakarta, were accused (among other charges) of smearing the streets with oil. (See Kompas, April 27, 1982.) 
the warung now had no real interest in these incidents. Not to talk of rumored incidents past, was not to see them, in retrospect, as ekses, and in a sense, not to see them at all. This unconcerned, utterly casual silence was at perfect odds with the post-Pemilu "political" soul searching and consciousness raising of the government and press. It seemed to confirm suspicions that, while Pemilu was a sukses, voters were somehow not really politically conscious. "Did the masses consciously give their support to a particular Pemilu contestant?" asked Topik magazine. 32 Warung conversations did not worry much over this question. When "Pemilu" was raised in warung in the last weeks of May 1982, it was with reference to Pemilu '87. A last whisper of rumors wondered whether the two "political parties" would be active in 1987; who might lead them; and what would happen if the parties were abandoned, or if they weren't. The rumors did not last long, but they signed the possibility of another sa'at.

One of the striking facts about Pemilu(s) is that the most active campaigners are kids in their teens and early twenties. They now belong to a New Order generation born after 1965 and trained in New Order schools. And yet, they are the ones most frequently criticized as thoroughly undisciplined and politically unconscious. Juxtaposed to the relatively recent ascent of Pemilu to its ritual status, this unruly fact suggests a rather weird coincidence of histories in 1987: that of a "Pesta Demokrasi '87" on the one hand, and (for lack of a better term) an "'87 Generation" on the other. If the logic of sa'at repeats itself, Pemilu 187 may secure its "ritual" position as a Pesta Demokrasi. Then again, Pemilu '87 could very well follow out sa'at's compelling logic, and ritually exceed itself. In any event, looking back now on the 1982 General Election in Solo, Ken Ward's initial thought holds true: "Historical events often seem more important to their witnesses than they do to the historians who judge them later." The same could be said of rituals and their ethnographers.

32. Topik, May 10, 1982, p. 5. 